\title{
Pers, demokrasi dan negara Indonesia Post-Soeharto: Sebuah perspektif
}

\section{Press, democracy and state in Indonesia Post-Soeharto: A perspective}

\author{
Herdi Sahrasad \\ Fakultas Filsafat dan Peradaban, Universitas Paramadina \\ Jalan Gatot Subroto Kav. 97, Mampang, Jakarta Selatan, DKI Jakarta 12970, Indonesia \\ sahrasad@yahoo.com
}

\begin{abstract}
The resignation of President Soeharto in May 1998 marked the end of new order era and started a fundamental change within democracy in Indonesia. As a democratic state, Indonesia arguably provides a system to guarantee the freedom of press and good environment of mass media; as the media is supposedly not to be power driven. Several factors have been observed to understand the relationship between press and democracy. Those are democratic revolution, freedom of press, political oligarchy, the role of students, and criminal democracy practice in Indonesia. This article found that under the President Susilo Bambang Yudhoyono-Boediono (SBY-Boediono) era, newspeople freedom in journalism was gripped by the practice of "criminal democracy" which continues to undermine the development of press freedom. To conclude, democracy in Indonesia is decayed by unjust practices from the political elites; it further affects the way press and mass media in performing their roles as the fourth pillar of democracy.
\end{abstract}

Keywords: press, democracy, oligarchy, poor governance, criminal democracy

\begin{abstract}
Abstrak
Berakhirnya masa jabatan Soeharto sebagai Presiden Republik Indonesia pada Mei 1998 menandai hadirnya era baru pemerintahan yang membawa perubahan fundamental dalam demokrasi di Indonesia. Sebagai negara demokrasi, Indonesia memiliki kewajiban untuk menyediakan kebebasan pers dan atmosfer pers yang baik dan bebas dari control kekuasaan. Beberapa faktor ditinjau untuk menemukan hubungan antara pers dan demokrasi, antara lain: revolusi demokrasi, kebebasan pers, sistem politik oligarki, peranan mahasiswa, dan praktik criminal democracy di Indonesia. Artikel ini menemukan bahwa di bawah pemerintahan SBYBoediono, kebebasan awak media dalam jurnalis memengalami hambatan dari praktik criminal democracy yang menghambat proses berkembangnya kebebasan pers di Indonesia. Simpulan yang ditemukan adalah, demokrasi di Indonesia mengalami berbagai permasalahan akibat praktik-praktik tidak benar yang dilakukan oleh elit pemerintahan. Hal ini mempengaruhi kredibilitas media massa dalam menjalankan peranannya sebagai pilar ke empat demokrasi.
\end{abstract}

Kata kunci: pers, demokrasi, oligarki, pemerintahan buruk, criminal democracy

\section{Introduction}

Under Reform era, relationship between press and democracy in Indonesia post Soeharto was full of complexity. Mass media as the fourth pillar of democracy endured pressure from political oligarchy of Indonesian elites, not only in political sector but also various strategic sectors, including national mass media industry. Therefore, function of mass media to control the elites did not work adequately. The condition required new perpectives to see the phenomenon comprehensively. In the system of the Old Order era of Sukarno's Guided Democracy (1959-1965) and Suharto's New Order (1966-1998) the government were known for committing repressive act such as suppressing the press and people. Sovereignty and the principle of law were under challenge. Moreover, the basics and important values such as human values and human rights were abandoned.

Research by Abdurrahman Surjomihardjo shows that started from the colonial period up to the New Order era, the hegemony on national press had been carried out by the state. Tragedy of press 
companies bans were something common at that time. It is shown from the data of the Press Council that during the Old and New Order era, dozens of journalists are captured for jail with 237 publishing licenses were being revoked (Surjomihardjo 2002).

Tempo magazine was one of the examples, experienced banned for two times before being reissued. Tempo was banned for first time in on March 13, 1982, for the manufacture of articles that indicate election fraud in 1981. The second ban was on June 11 edition 1994, because of the articles about the purchase of German used warships by the government. Unlike Tempo, the Indonesia Raya newspaper was banned once and never being republished. Bernas magazine journalist, Udin, once being killed and never revive again. These evidences indicate how the press and the history of power were close, inside and outside (Batubara 2007). Repressive situation on political power in one side and economic liberalization in the other side became a contradiction. In one hand, State had the responsibility protect the accumulation of capital while at the same time State also provided room for the development of democracy, as a capitalist state guarantees both the right of ownership and political rights (Kunio 1987).

The stream changes in 1998 through the student movement to reform democracy, human rights, people's dignity and welfare, appeared from the birth of the middle class and educated community. There were other factors which had significant influences such as life integration between Indonesia with the world community through economic network, information, sharing ideas and experiences. Democracy has basic principles namely human dignity and human rights which were being respected and protected without discrimination. Democracy also has a civil rights guaranteed by the constitution, such as the right to liberty, property and equality before the law.

\section{Press freedom and democracy}

Before the era of democracy in 1966-1998, the newspapers can be issued only if they gained SIUPP (press publishing business license), which was very expensive and controlled by the Suharto regime. However, when the reform era came, people began benefiting from the freedom of the press. Without any discrimination, the license to publish mass media is more accessible and open to the public. Yet, the extensive issuance of press publishing also increases the pro and contra opinion due to several factors, such as, public and Government had been accustomed with the old authoritarian model. Another factor was the fact that the first period of the press freedom increases the quantity of mass media that live in the new air of freedom.

When the reform in 1998 rolled out in Indonesia, the national press got up from the ground and the press freedom was open again marked by the enactment of Law No. 40 of 1999. The various obstacles that threaten national press were being dismissed. The SIUUP that was applicable in the era of New Order was no longer needed, anyone can issue press publications anytime without complicated requirements.

In the Article 6 of Press Law No.40/1999, national press carries out the role as follows: (1). Meet the public's right to know. (2). Affirm the basic values of democracy and human rights and respect for diversity. (3). Develop a common opinion based on accurate and precise and right information. (4). Conduct supervision, criticism, corrections and suggestions on matters related to public interest. (5). Fight for justice and truth. Professionalism means ideology that values professional skills or personal abilities in general, as the main tool to achieve success.

In Indonesia, the wind of reform was blow hard that wide corridors of democracy unfold. Liberalization takes place massively. Public spaces, which previously were filled with spider webs of power that every moment could fetter the freedom of the press, had opened more widely. Alternative voices that for so long settled behind the cubicles of public silence suddenly wafted out. The development of the Indonesian press recently has noted some important indications of change dealing with the press after Soeharto's New Order. First, the deregulation of media made by the post-Suharto regime as shown by the easiness in gaining a license and the revocation of SIUPP 
system has led to widespread press publications. Unfortunately, the increase in the quantity of media is not accompanied by journalism quality improvement. While the media that tends to be partisan repeatedly holds the "language sensationalism" as seen through the selection of the title (headline) that is bombastic or makes garish cover designs, at the same time entertainment magazines and tabloids do the "vulgarities" and "eroticity" of sex information.

That situation is known as negative press. The Indonesia recent society is the society overflowed with information in the form of images, text, sound and visual communications. Media-saturated society also leads to the media narcotization for the community. "Narcotization" is a term used to describe the negative effects or deviant consequences (dysfunction) of mass media. The term actually comes from Paul f. Lazarsfel'd, and Robert k. Merton. In their essay, Mass Comuniation, Popular Taste and Organized Social Action (1984), they use the term "narcotizing dysfunction" to refer to the social impact of the media, which often overlooked. They believe that the mass media cause apathy.

Second, it is the emergence of the so-called "new media" in our society lately. To mention them is the Internet and increasingly sophisticated multimedia technology. Internet access brings a new culture in the utilization of spare time (leisure time). With the Internet, the boundaries of space and time have been compressed. More value and benefits can be taken and used by media users, for the sake of efficiency and effective day-to-day activities, so it is not excessive if that category is called a positive press. Third, it is the strengthening of the phenomenon known as a media "imperialism" thesis. This phenomenon is due to the transnational media globalization and the invasion of imported entertainment products that dominate the domestic media market.

Journalists have a heavy duty. "Journalists must hold firmly the truth and be faithful to the people," said Bill Kovach and Tom Rosendstiel (2001). Journalists work for the good of society. Working to verify the news, they must be transparent and systematic, and should be independent. They should avoid unnecessary engagement with political parties, rulers or employers. How can a journalist hold the responsibility to make report accurately about a person to whom he/she has personal relationships, in terms of intimacy and loyalty? There should be a personal distance for journalists to report and evaluate news independently. From there, the truth emerges, that the journalists have the credibility as transmitter of the story. This confession is not obtained as taken for granted. But, repeatedly and continuously, it is pursued through a variety of codes and conventions of truth on which the audiences can put their faith in (Mc Nair 1998).

\section{Democratic revolution}

The resignation of President Soeharto in May 1998 which marked the end of the New Order era in writer's opinion is a "democratic revolution"—not just a democratic reform." This event started a fundamental change on Indonesia democracy face, from a "guided democracy" ala Soeharto toward a constitutional democracy that provides opportunities to people and all sectors of civil society to control the power which is run by the executive, legislative and judicial board.

However, it need to take into account that a victory in the struggle for democracy in 1998 faced a serious threat when the actors or parties involved in that struggle (or so-called reformist) trapped in the euphoria that makes the upheaval and revolution as the ultimate goal. In fact, the upheaval and revolution should be seen as a way in an attempt to seize the objective. We must be aware of a revolution followed by another revolution, it has the probability to create the recurring violence and state failure.

Today, in the post "democracy revolution", it takes a strong press in Indonesia which requires commitment not only for the purpose of the revolution itself, but also to realize the objectives of democracy, social justice, welfare and security. The necessary conditions of strong press are already in our midst. The umbrella of law is also reliable. In Law 40/1999 about press, particularly Article 4 states that (1) freedom of the press is guaranteed as the right of citizenship, (2) the 
national press is not subject to censorship, prohibition or ban on broadcasting, (3) to guarantee the freedom of the press, the national press has the right to seek, obtain, and disseminate ideas and information; and (4) in the news responsibility before the law, journalists have the Right of Reject.

The Legal and political framework is supposed to support press to seek and maintain those principles. But, at the same time each member of the press is required to have a strong awareness that he/she responsible for all activities of journalism. Members of the press are not the follower of jingoism or extreem patriotism (for anything) and forget their obligations and responsibilities for their history. Indonesian press members have the law that lex specialis because they represents the interests of society, not the interests of themselves or other small groups.

So far we have yet to see the press community in Indonesia who think seriously and outline a definite direction of the press struggle. There has been no common agenda. That is why we are now seeing the media and the press becoming jingoists. They are very loyal to the interests of particular groups, both business groups and political groups, including the owners of capital, and ignore the greater and nobler purpose. Whereas, in fact, the main function of the press is as a tool of control and to shape public opinions, as what have been being discussed by experts that the press has a function of social control and shapers of public opinion (Chomsky 2006). But, in reality the press is facing the problem of criminal prosecution and even imprisonment, whereas Law No. 40 of 1999 ensures that the press offenses are civil cases, be resolved amicably through mediation played by the Press Council established independently by the state.

The facts tell us that at least until present, capital has won the battle, in which the owners of the capital has more freedom over the State and the press. For example, in the case of TomyWinata VS Tempo, the Supreme Court eventually pronounced Tempo a winner although the two previous Court, the Central Jakarta District Court and the Supreme Court of Jakarta won Tomy. Meanwhile, in the case of the Times Magazine, the Supreme Court pronounced Suharto for the victory. Thus, the reality shows that the Tempo victory has not become jurisprudence in general. Actually, in the same case of libel by the same agency, there are two opposite judgments. It was here that the experts see the failures of capitalism in developing countries, which have been raised by the State bureaucracy, because capitalism in principle cannot be developed in the situation in a country that uses double standards.

The empirical facts above provide theoretical confirmation that there is no legal certainty to ensure the freedom of the press as Act No. 40 of 1999. To rebuild the basic functions of a free press, it is time for the state to impose the Press Law as a special law (lex specialist). For the newspeople, it is also necessary to hold society to realize citizen journalism. Community media in various forms, print, electronic and audio visual needs to gain priority as the existing capital to the freedom of the press towards the realization of substantive democracy.

According to the theory of the liberal press, the press should have as wide as possible freedom to help people find the truth. To seek the truth, human being needs freedom to seek information. In a liberal society like in Europe and North America, the freedom of the press is the main pillar of liberal democracy as the classical theory stating that the mass media function as 1) public spaces, besides functioning as 2) supervisor (watchdogs) to the government as it is described by Sukosd in Media and Public Policy. In this case, Siebert and Peterson have stated that the press is the fourth pillar (fourth estate) after the executive, legislative and judicial branches (Siebert 1963).

\section{The fourth pillar of democracy}

Indonesia has yet to be called a democratic country if not accompanied by press freedom, although theoretically it has been running the principles of democracy. The press is the fourth pillar of democracy. The more a government guarantees the freedom of press, the more democratic the government is. In the context of nation life, the press plays an important role. Implying freedom of 
the press is guaranteed in article 28 of the 1945 Constitution, which basically says that freedom of expression either individually or in group is a fundamental right of citizens.

So, how about our press freedom index? Here I would like to show a report from "Reporters Sun Frontieres", an independent press agency based in Paris, France, in 2010 that issued a release of the World Press Freedom Index 2009. In the index, the press freedom in Indonesia was on 101 of the 175 countries with a score of 28.5. The position of Indonesia increased from the previous year that was ranked 111 scoring 27. Although Indonesia is considered the best in Southeast Asia, but rank 101 is still not a satisfying achievement. It means that there are still other 100 countries at a higher level of press freedom comparing with our country. Meanwhile, the top-rank was occupied by developed countries that already have an old democratic and press tradition, such as Denmark, Netherlands, Australia, the United States or Japan.

On the other hand, countries that are in lower-ranks mostly tend to have political authoritarian system, such as Iran, China or North Korea. When we look the trend, according to the 2010 World Cup of South Africa, the freedom of the press index of Indonesia from years to years does not go further to the level of big 100. In 2003, Indonesia ranked 111 with a score of 34.25 (scale numbers 0 is the highest and 100 is the lowest).

In the later years, Indonesia ranked fluctuatively, 117 in 2004, then rose to 105 (2005), and then rose again to 103 (2006) and 100 (2007). In 2008, Indonesia's ranking slipped back in 111, one of which it was influenced by the decision of the Supreme Court (MA) won a lawsuit against TIME magazine by Suharto family. In 2009, Indonesia improved its position. The conclusion of the previous data is the level of press freedom in Indonesia was still not as expected. Indonesia is the third largest democracy in the world, but the press is still far below other democratic countries. Why? The low ranking of freedom of the press insisted that Indonesian press at the time of the Reform Era is still not completely free. There are still many challenges to face to uphold the freedom of the press as the fourth pillar of democracy. There are still classical problems in the press freedom in, such as a lawsuit against the institution of the press, violence against journalists, and even murders on journalists. If left untreated, the press freedom ranking of Indonesia will sag again.

Almost similar to the New Order era, the space for the press in the era of reform is still limited because there are many lawsuits against the institution of the press. Press offenses arise largely because of dissatisfaction from some parties on news released by mass media. In many cases, the media was sued based on the article 310 about Code of Criminal Libel and Slander Article 311 of the Criminal Code of deployment.

Those Articles are a lariat for journalists or other press institutions, for example the case of the Suharto family with TIME magazine, Reymond lawsuit against seven media related to the news that seemingly accused him as "illegal operator in gambling", and many other cases. Most of them use the plaintiffs' criminal law against the press. But, fortunately, many cases can be resolved through the mediation of the Press Council or through a peaceful settlement.

So far, the press dispute is set to refer the the Press Law. Article 5 of the Press Law states, all public complaints related to the institution of the press will be facilitated by the Press Council. In the case when the press goes wrong, the party who objected has the right of reply. However, this is often overlooked and cause frequent dealings of reporter brought to the court.According LBH Pers reports, there are at least 108 lawsuits using the press and defamation article in the period 20032007. The second issue that is why the index of press freedom in Indonesia is still relatively low is the violence against journalists. The violence usually occurs when a reporter does journalistic duties or when there are people who feel offended by the content of news written by journalists. According to data from the Alliance of Independent Journalists (AJI), the number of cases of violence against journalists in 2009 is 71 cases, increasing from the previous year as many as 54 cases. The forms of violence include physical violence, such as beatings, torture, attacking and even 
murder. Meanwhile, the non-physical violences which are often done to the journalists are the restrictions of reportation, deprivation of news footage, threat or terror.

Meanwhile, there is tendency of regulation that increasingly has no respect to freedom of press made ranking of Indonesian press freedom was unsatisfying. In 20 October 2010, Reporters sans Frontieres (RSF), a non-profit institution from Paris, released index of press freedom in 178 countries. Position of Indonesia was downward from 101 in 2009, to 117 in 2010. In Asia, the position of Indonesia were far under Hong Kong with index of press freedom 34, South Korea (42), Taiwan (48), and even Timor Leste (94). Meanwhile, Finland, Island, Netherland, Norway, and Sweden were in the upper position. In this regard, activist Tifa Foundation R. Kristiawan noted that Freedom of press in Indonesia throughout 2010 was indeed fully with various cases of insult. There were may cases of murder of journalist happened in that time, characteristically regular criminal such as in Palembang case, "containing" political such as in Merauke case or caused by riots in Ambon. Editor Head of Playboy magazine served a sentence 2 years jailed without mechanism of press court as mentioned in Circulated Letter of Appellate Court. In Depok, a journalist was beated by officer of Local Election Commission. Head of SCTV confessed that he had been intervened by Ministry of Law and Human Rights not to publish investigation reporting on sex business in prison. There are still many examples proven that throughout 2010 violence to freedom of press in Indonesia had the tendency to increase (Kristiawan 2011).

Besides technical matters, other thing that needed to be noted is legal regulation produced defamation. Criminalization to every member of public actually rooted in politics of colonialism. This paradigm had firstly gone into effect in Dutch-Hindia by government of Dutch colonialism through Wetboek van straftrechtvoor Nederlandsch-Indie in the early of 1918. The legal regulation used by the colonial government to control freedom of expression's people in colonial land. Then, Indonesian government adopted it to Book of Penal Code (KUHP). In early times, there were 30 articles in KUHP could bring journalist and people to prison. After Constitutional Court cancelled article of degradation to president and vice-president in 2008, there were remained tens of articles potentially could bring people and journalist to prison in the name of aspersion. Ironically, Netherland itself has "pulled" articles of aspersion from its Book of Penal Code.

Table 1.

Position of Indonesia in press freedom index by reporters sans frontier

\begin{tabular}{ll}
\hline Year & Position \\
\hline 2001 & The most free in Asia \\
2002 & 57 out of 139 countries \\
2003 & 111 out of 166 countries \\
2004 & 117 out of 167 countries \\
2005 & 105 out of 167 countries \\
2006 & 103 out of 168 countries \\
2007 & 100 out of 169 countries \\
2008 & 111 out of 173 countries \\
2009 & 101 out of 178 countries \\
2010 & 117 out of 178 countries
\end{tabular}

Source: Reporters sans Frontier, http://en.rsf.org/

If we look at the table from perspective of democratic transition, prevailing regulations in reformation era should give priority to democratic characters. However, this has not happened in product of media law in Indonesia. Instead of doing review, colonial inheritance articles in KUHP even used as consideration basis to make new regulations. ITE Law, for example, still use paradigm of aspersion criminalization. This matter indicating that freedom of opinion guaranteed by Constitution of 1945 and product of founding father of this nation struggle have not yet realized. There are significant numbers of colonial and authoritarian element reducing guarantee of freedom to state opinion. Even worse, it is still happen today (Kristiawan 2011). 
Supposedly, after 2011 there should be a more advanced stage in the development of democracy in Indonesia. All the stake holders of the press must be able to sit together and discuss the ideals of freedom, ideal reform, and ideals of a democratic Indonesia that embody social justice, welfare, safety and freedom.

\section{Press, democracy and political oligarchy}

Under the President Susilo Bambang Yudhoyono-Boediono (SBY-Boediono) era, the condition of the people was gripped by the practice of "criminal democracy" which continues to undermine the joints of national life. There was a strong trend that reform has been hijacked by the elite, and the politics of money and the violence increased. On the other hand, the mass completely ignored the fraud and intimidation by the elite to reign. The elites are also thought to have done dirty practices, such as bribes to be elected as the member the House of Representatives, district heads, governors and so on. After the New Order era with its authoritarian rule, the current situation is toward a transition to a constitutional democracy. But, in the current leadership, the practice of democracy is worthy to be called criminal democracy (Supriatma 2009).

Questions may arise from public, "Is today democration that we really want? Does democracy only work for interests of a certain elite group? Democracy is only procedural, only in the form of elections, presidential or local leader elections, but may not improve the lives of the people. The legislative and executive candidates have to spend a lot of money and expecting for return later through corruption. Reform seems futile. Press see what is happening in Brazil with 8 years reform the country could be restored after the country were burried among the countries of Latin America. Japan which was destroyed in the World War just needs 30 years to catch up western countries. Malaysia through Mahathir needs less than 25 years to change people become prosperous. China needs less than 20 years to be rich. So, what about Indonesia?

The press sees that it only needs a few brave people and support from all communities to make changes in Indonesia. Indonesia actually has a lot of smart people, but only very few daring to declare the truth. One of the ways is through the funding of political parties. The financial reports of political parties must be transparent and verifiable. Press notes, the cost of political elite of the legislative, executive and judicial authorities in 2010 amounted to Rp. 19,5 trillion. In fact, the budget of the health insurance for the poor is only Rp. 4,5 trillion. The cost of political campaigns in Indonesia is also very expensive. Not only in the local elections and legislative elections, even the cost of presidential campaign can increase 10 times in the next 5 years. In 2004, former Vice President Jusuf Kalla (JK) said he and Yudhoyono needs Rp. 120 billion to fund the campaign. But for the 2009 elections, the price rose 10 -fold.

Several years ago, the president SBY was surprised while seeking refuge to God hearing the high cost of legislative and presidential elections to be held in 2009. "Is that true, the Legislative and presidential elections cost ten trillions? Masha Allah (what God wills), really, really expensive," JK imitated SBY at that time.JK assumed that the huge cost is due to the vast and wide of the area of Indonesia. Another factor is because 75 percent of politicians are employers (Wisesa etal. 2011). As an illustration, Democratic Party spent Rp 214.44 billion only for advertising in 2009. Yet, the party reported to total cost of the campaign to the Election Commission only Rp 243.8 billion, the difference is only $\mathrm{Rp} 29.36$ billion of the entire cost of advertising alone. More miraculous, some parties even reported their campaign cost that was less than their advertising cost, like Golkar who claimed the campaign cost was only Rp 164.5 billion, but its real advertising cost was $\mathrm{Rp} 277.29$ billion.

PDI Perjuangan (Struggle Democratic Party) reported campaign expenses of Rp 10.6 billion, but it wasted advertising funds of up to Rp 102.89 billion. Similarly, the PKS (Prosperous Justice Party) claims to spend $\mathrm{Rp} 36,5$ billion for the campaign, but its advertising spending reached $\mathrm{Rp} 74.65$ billion. The political fund is very expensive and it becomes investment that should be returned when the person occupies public office in the parliament or in the executive body. The salaries and 
facilities received are certainly not enough to restore the investment, so corruption becomes the only way to restore the investment and raise capital to assure the second period of office. Meanwhile, the lack of political infrastructure also causes political parties and candidates cannot raise donations from members or supporters, so that they rely on main contributors, mainly businessmen or investors, and this lead to political parties and politicians become less independent (Siregar 2010). In this case, the main contributor will then seek compensation from the government projects that encourage political corruption. The lack of political infrastructure also raises the problems of political representation.

The crisis situation grows because of politicians who do not have a relationship with constituents tend to ignore the public voice and proceeded to spend the budget for abroad trips or build the House of Representative building that gets a broad rejection from the people. There is a strong symptom that politicians expose corruption to restore the economic capital that was used in politics, and that is the high cost to be born in criminal democracy today. As a result, criminal democracy is increasingly widespread. The situation becomes difficult because of rampant corruption stretches from the center to the regions, and the high cost of politic becomes the source of problems until recently, like the road with no end, no solution.

When the world highly praises Indonesia, the press in Indonesia is just being skeptical. The World Bank assesses Indonesia as a country with other 18 world's biggest economy countries based on the gross domestic product of more than U.S. \$ 700 billion. All macro-economic indicators in 2010 were considered more stable and sturdy. The reserve up to December 2010 reached U.S. \$ 94.7 billion. At the same time, export value reached the highest value, $\$ 150$ billion. The world also praised Indonesia has become one of the world's economic giants. World Economic Forum's competitiveness in the report entitled The Global Competitiveness Report increases Indonesia's ranking. Indonesia was considered successful in achieving economic development pattern, from a factor driven economy or economic development arrangements for raw materials-based economy to be efficiency driven economy or economic development arrangements developed countries that are supported by the efficiency, competitiveness and the use of progressive science and technology.

The Economist, December 2010 in an article titled The World in 2011 stated that Indonesia as a new economic power has a good perspective when the world economy in crisis. However, the Indonesian press remains skeptical because the problems of corruption, ineffective governance and weak leadership of SBY disappoints people's expectation. The press was very disappointed because the era of Yudhoyono was touted as one of the stars of emerging market is the most corrupt country of the 16 investment destination countries in Asia-Pacific. Until the era of SBY-Boediono, the elites suffered a crisis of ethics and morals so that corruption was rampant, rich-poor high gap, and crisis of public trust in society to the authorities. The survey conducted by Political \& Economic Risk Consultancy or PERC in 2010 said that Indonesia ranked first as the most corrupt country with a score of 9.07 from a value of 10 . The second position was occupied by Cambodia, followed by Vietnam, the Philippines, Thailand, India, China, Malaysia, Taiwan, South Korea, Macao, Japan, the United States, Hong Kong, Australia, and Singapore as the cleanest country. In the rank number ranging from 0 (the cleanest countries) to 10 (most corrupt country), the "acquisition" of Indonesia increased from 7.98 in 2008 and 8.32 in 2009 to 9.07 in 2010.

PERC validity of the findings can be debatable. But, the case of "Crocodile vs Lizard" in the late 2009 had consequences and overlapping into the case of "Case Broker", "The Case of Century Bank", "Judicial Mafia Case," "Fat Police Officer Case Account", "Gayus Case", "Case Tax broker ","Case photo tennis tournament," along with "BI Deputy Governor case" and other cases that hit the parliament, bureaucracy, law enforcement agencies and politicians, simply confirm the findings of PERC. The executive, legislative and judicial branches of government in Indonesia have been tarnished by ethical-moral crisis.

In the case of poor-rich gap, the poverty level in 2010 according to calculations from the Central Bureau of Statistics (BPS) that is usually more optimistic, the level was not much away from the 
poverty rate in 2009. Poverty rate in Indonesia in March 2010 reached 31.02 million (13.33 percent), decreasing 1.51 million compared with the data in March 2009 which amount to 32.53 million (14.15 percent). They were classified as poor by the BPS that they per capita spending were less than Rp 211.726 per month, or Rp 7.000 per day. Meanwhile, the group with spending 10-20 USD (Rp 90,000 - Rp 180.000) per capita per day increased from 0.4 million in 2009 to 2,23 milion people in 2010. The poverty rate indicates the weakness of spirit and performance of the government to eradicate poverty, while at the same time, corruption spreads widely.

To fulfill the promise of drastically reducing poverty, SBY-Boediono cabinet rests on the motto: pro-poor, pro-jobs, pro-growth. However, recent data (March 2011) still recorded the number of poor and near-poor respectively 30.02 million (12.49 percent) and 27.12 million (11.28 percent), or 33.77 percent of the population of Indonesia. This is a high number, in fact the limit of the poverty line and near-poor is relatively low, i.e. per capita/month to Rp 233.740 (poor) and Rp 280.488 (near-poor). The promise of President SBY in his first period that poverty in 2009 would be suppressed to 8.2 per cent was far from reality. Similarly, the promise to reduce the unemployment rate from 8 percent to 5.1 per cent of the labour force (2009) is also far from authentic. The actual number has not progressed significantly since 2002. While at the same time, 25 per cent of children under five years were reported suffer from malnutrition. Maternal mortality, although reported to fall sharply from $307 / 100.000$ to $226 / 100.000$ birth (BPS 2010), was doubted by the UN agency that evaluates to an increase in maternal mortality. Currently, the criterion for those earning under U.S. \$ 2 is considered as the poor, the number of poor people in Indonesia reached fantastic: some 120 million people! That number has not changed much since 2004 when the President began his presidency (Hadar 2011).

Meanwhile, the press and NGOs also showed waning morality "Unity in Diversity" as one of proofs of the existence of moral crisis. In October 2010, the Indonesian Survey Circle (LSI) announced findings that the level of tolerance for diversity based on the understanding of the Union decreased dramatically. Instead, the justification of violence in the name of religion increased significantly. To see the extent of the tolerance, LSI questions about the violence experienced by Ahmadiyah. From the results of the survey in September 2010, as much as 30.2 percent of respondents approve of violence against Ahmadiyah. These results were far greater than the results of the 2005 survey that only 13.9 percent. This was a strong evidence that diversity in Indonesia more damaging and threatening. This situation was also a concern of the press in Indonesia in a large scale.

\section{Press, students and state}

Today, the press posses a significant power to publish critical voices of students on SBY regime. Press broadcasted many concerns and fears among students from various universities in Indonesia on the life of the nation-state in current era of constitutional democracy, which is rational. Students as moral and strategic strengths were expected to correct, suppress, and fight the ruling elites that no longer work for the interests of its people. SBY-Boediono regime is aligned with the perspective of Gaetano Mosca (Class Law, 1939) that is about a ruling class and a ruled class, it seems no leaders but rulers. The first class whose numbers are smaller performs all the functions of politics, monopolizes power and enjoys the benefits of that power, while the second class of people whose numbers are greater is ruled, regulated and controlled by the first class, left in misery, hardship and loss.

Now, the ruling class is about to forget people, ignoring campaign promises and damage the joints of the state and nation, it is a calling for students and activists to stop and change it. According to Milan Kundera, "the struggle of man against power is the struggle of memory against forgetting" (Kundera 1979). We can find thus concerns and fears of Indonesian students which was published in Kompas (issued July 7 to 11, 2011) based on interviews with student activists, among others, the Student Executive Board (BEM) UI, Sharif Hidayatullah Islamic State University, Gadjah Mada University, Hasanuddin University, ITB, UIN Sunan Kalijaga, UNJ, University Padjadjaran, Surabaya UNTAG, UNY, USU, Airlangga University, UB, UMM, Undip. UMY, UII, Trisakti, 
Atmajaya and activists from Cipayung groups such as the General Chairman of PB HMI Fajrieansyah Noer, Chairman of PB PMII Addien Jauharudin, Chairman of the Presidium of GMNI Twedy Noviady, Chairman of the Presidium PMKRI Stephen Gusma, and Chairman of the PP GMKI Jhony Rahmat.

In short, the authors note the various concerns and worries of students who submitted to the Indonesian press as follows:

First, fear and concern over the messy and chaotic situation by the destruction of the state and political order. Political elite has ignored the demands and problems of people and instead chose pragmatism and money. Thus, the situation of Indonesia is assessed by the students as very dangerous and risking the fate of the country. The government under President Susilo Bambang Yudhoyono is currently being considered to have deviated from the spirit of the 1945 Constitution. Officials and political elites more concern and busy over the political agreement for individual or group interests, and they forget the responsibility to fight for the interests of the people. Many ministers were choosen based on calculations of political coalitions instead of professional abilities. In the chaotic condition, the needs of people are forgotten. They are abandoned in difficulties of life. Food security is bad and food prices are expensive. Low-cost educational programs for people are pressed by the market hegemony, a neoliberal-oriented.

Second, the weak national leadership and the poor people of Indonesia have prompted stuck in a pile of problems with no clear resolution. In order to change it, students believe that there should be a continuance of the spirit of the Reformation in 1998 that had not been completed to create an alternative leadership figures. In addition, there are politicization of law and law enforcement taking place in a selective logging. The condition of the nation lately needs a deep concern. Corruption is rampant in which the major cases handled unseriously, such as Century Bank bailouts, tax mafia, or the alleged bribery SEA Games athletes homestead project involving the former General Treasurer of the Democratic Party Muhammad Nazaruddin. Law enforcement is not running because of the political elites are taken hostage to corruption cases. In students' point of view, the political elites think only their own interests and groups. They had ignored the aspirations of people and communities complete resolution. People have even lost confidence to government.

Third, students are anxious and worried because the country is moving without direction, a leader, and without any encouragement ahead in almost all sectors of life. As a result, people become victims because there is no policy that encourages prosperity. As an elite supreme ruler, President Yudhoyono has a good concept in a speech, but never been really implemented. The President as executor the mandate of the people must have the courage to change bad ministers. The government and the political elite is now busy waging political games for personal passions or certain groups, and they are also considered to be betrayed the tasks mandated by the 1945 Constitution, which protects all the people of Indonesia, promoting prosperity and intellectual life of the nation. Commitment in safeguarding state sovereignty is also weak, with the dominance of foreign interests in the strategic management of economic resources, such as mining, banking, and telecommunications.

Fourth, the students see the oligarchy and the role of the central figures of the party damage political cultures in Indonesia. Political parties are handled by few powerful persons and have nearly unlimited capital. Their ideology is power and money, although they claim recognizing Pancasila ideology, but their behavior shows the opposite. For Islamic parties, they said their ideology is Islam, but their manner is anti-Islam. The impact of those matters is the weak law enforcement and the national economy, which serves as a slave of global economic interests and international capitalism. The accumulation of various critical issues that the nation has been frustrating society as well as emerging radical movements in response to dissatisfaction with the situation of the country that politically devastated, helpless in law enforcement and economically weak. Therefore, without strong government leadership and national and political reform, the state will lead to the abyss of failure. 
Fifth, students see there are serious problems but remain unsolved is the portrait of poor governance. Not only not sensitive and responsive to prevailing conditions in society, the leadership of President Susilo Bambang Yudhoyono and Vice President Boediono were assessed also not more than only to maintain power, rather than meeting the community needs. Communities also noted, the government creates more polemics rather than achievements (Kompas 2011). What is worried and concerned about by the students above has confirmed the findings in the study done by Richard Robinson and Vedi Hadiz R, stating that although Indonesia was apart from the snare of the New Order authoritarianism, post-Suharto Indonesia has not been free from the snares of money political oligarchy. The networks of patronage and the allocation of power and public wealth get a new room, namely political parties and parliament. As a result, the actors who originally entered as a reformist force eventually dissolve in the marriage between predatory capitalism and democratic politics. The oligarchy networks of the New Order heritage then work on electoral systems, political parties, and parliamentary in the Reform era, even further not only to national politics, but also into local politics. This oligarchy hijacks democratic institutions like political parties, elections, and parliament, and is able to retain power, since they are able to master the sources of wealth and control people's economic sources, purchase law and its officers, enforce their power by manipulating democracy (Robison \&Hadiz 2004). In this case, the criticism against the government of SBY-Boediono has made repeatedly by the interfaith group, Rector Forum, NGOs, and society in general. However, government is indifference, continuing to work in the style of business as usual, apparently convinced there would be no social and political turmoil that could bring them down from their power before 2014.

\section{Press, oligarchy, and criminal democracy in Indonesia}

I believe that the press should continue to be the fourth pillar of democracy. Press upheld the responsibility to prolong and carry out its vision and mission to be consistent, struggle and uphold the truth and justice, and to maintain the principles of good journalism, as the teaching of Bill Kovach and Tom Rosenstiel in The Elements of Journalism, What Newspeople to Know and the Public Should Expect, which encourages journalists/newspeople (Kovach \&Rosenstiel 2007).The newspeople's and my anxiety begins with a question about the main problems that hinder the democratic system in Indonesia. Oligarchy as a phenomenon of power which only arranged by certain group of people has become an obstacle to democratization. Newspeople and journalists are very concerned on how the power with wealth-oriented becomes the basis of oligarchs with incredible greed. Oligarchs, for the perpetrators of the oligarchy being called, are very strong. The oligarchs could also become elites when their goal is to preserve wealth. In this case, the press becomes a bee without a sting in the control process over them.

Those problems convinces the findings of the study by Richard Robinson and VediHadiz R, stating that although Indonesia was apart from the snare of the New Order authoritarianism, post-Suharto Indonesia has not been free from the snare of the political oligarchy of money. The networks of patronage and the allocation of public power and wealth get a new room, namely political parties and parliament. As a result, the actors, who originally entered as a reformist force, eventually dissolve into the marriage between predatory capitalism and democratic politics. These oligarchy networks of the New Order heritage then work on electoral systems, political parties, and parliamentary in the reform era, even they go further not only to the national politics, but also into local politics. This oligarchy has hijacked democratic institutions such as political parties, election, and parliament, and has been able to retain power, since they are able to master the sources of state wealth and control over public economic sources, purchase law along with its officers, and enforce their power by manipulating democracy (Robison \& Hadiz 2004).

Prof. Jeffrey Winters said that an oligarchy in Indonesia becomes a major problem due to the loss of the role of law as a brake to minimize the oligarchs' domination. Contrasting Singapore's legal system which runs without democracy, Indonesia committed to democracy without the rule of law. In the case of the rampant oligarchy in Indonesia, we (the journalists, news people) are witnessing 
the fall of Suharto actually does not produce democracy but oligarchy. It is quite interesting to see the money as the power source of the oligarchy, yet it is more interesting to see the oligarchs use their money to defeat the journalists. The results of surveys on Indonesian politics are not infrequent to conclude that 13 years of the Reformation did not bring significant changes in Indonesia. Even, the New Order era is considered as a better era than the time of the Reformation.

We know how the oligarchy of power still becomes the shackles of political parties. Thereby, it disrupts the democratic process, even within the parties themselves. The oligarchy power also can be seen from other life sides. If we see from the accumulation of wealth, in the Reformation era, especially in the era of President Susilo Bambang Yudhoyono, it is clear how the rich gets richer. The press in Indonesia is like bees without stings in facing the lunge of oligarchy. People were shocked by how much money Indonesian oligarchs can save in Singapore, year by year their immense money increases steadily. The results of a study by Professor Jeffrey Winters at Northwestern University, United States, (Winters 2011) with reference to the data from Capgemini and Merrill Lynch showed, in 2004 when Yudhoyono was elected President for the first time, there are about 34,000 Indonesians having assets of at least 1 million USD posted abroad. Of that total, 19,000 of them are Indonesian citizens who live semi-permanent in Singapore. That number increased to 39,000 in 2007 and became 43,000 in 2010. Their wealth average in 2010 was US\$ 4,1 million. Their cumulative wealth is US\$ 177 billion, and US\$ 93 billion of which they post in Singapore. Although the 43,000 wealthy residents represent less than 1 percent of Indonesia's population, their wealth is equivalent to 25 percent Gross Domestic Product (GDP) of Indonesia. Moreover, there are only 40 Indonesian people whose wealth was equivalent to 10.3 percent of Indonesia's GDP. Winters' study was published by Inside Indonesia magazine No 104, April-June 2011 edition which was published in Australia, also comparing the 40 rich people in Indonesia, Thailand, Malaysia, and Singapore.

The total wealth of 40 Indonesians is the highest i.e. USD71,3 billion, compared with US\$ 36 billion of Thais, Malaysians with USD51,3 billion, and USD45,7 billion of Singaporeans. The concentration of wealth index score of the 40 Indonesians is 6.22 or 3 times of Malaysians (1.65) and 25 times that of Singapore which is only 0.25. The gap between rich and poor in Singapore is not as high as the gap in Indonesia. Oligarchy in the New Order could still be properly managed by Soeharto. No matter how wealthy they are, all they are under Soeharto's control. What is happening now is the oligarchs are wilder, since nobody is able to master them. They may pay politicians during the campaign, buy law makers and not impossible can also specify which officer should be appointed or elected to public office.

If we look at the book Oligarchy (Cambridge University Press 2011), written by Jeffrey Winters, professor of political economy at Northwestern University, Chicago, it looks that oligarchy exists in various types or "families": warring oligarchies, ruling oligarchy, sultanic oligarchies, and civil oligarchies. Each type of the oligarchies retains material superiority: land, money, buildings, or property assets. In examining the poor-rich inequalities in the world, Winters suggested a difference between property rights and claims for property. Because the number and type of properties (land, buildings, assets) are always smaller than the population, so what he calls "the revenues defense industry" emerges everywhere (Sudarsono 2011). This industry consists of many institutions who responsible for law and political lobbying to protect civilian properties owned by the oligarchs. They are occur in the form of legal consultants, management consultants, accountants, lawyers, civil law enforcement agencies, legislative bodies, even members of political parties in government and parliament.

In the U.S. and Singapore, civilian oligarchies have been so strong that they master the tools of state law to maintain their wealth of financial and banking oligarchy. The case of U.S. government bailout fund to rescue companies and investment banks in the post-crisis 2007-2008 proved that the law had been to safeguard the interests of the 10 largest banks from lawsuits. None of the leaders in the U.S. banking financial company is touched by a lawsuit because the law about it is still "not clear". Banking oligarchs have made themselves "too big to fail." Precisely they too much master 
the law until they acquire impunity (Sudarsono 2011). Jeffrey Winters observed that the press/media has limitations to face oligarchies in democratic countries in Southeast Asia such as Indonesia and Philippines, where the sultanic oligarchy turned into a "criminal democracy", democracy without the rule of law. Financial and property oligarchies in both countries have mastered the revenues defense industry that they control to avoid income taxes or to protect themselves from environmental pollution lawsuit. The importance of the research on press/media, oligarchy and democracy in Indonesia and Southeast Asia is to find relevant academic studies for the effective press/media's roles and functions in the democracy life and their contribution to strengthen the press/media as the fourth pillar of democracy in order that the constitutional democracy is not hijacked into criminal democracy.

\section{Criminalization and defamation}

One of the serious problem in Indonesian press is defamation. I have seen many defamation has been launched to the newsmen in Indonesia. This defamation makes many journalists disappointed, disturbed and frustrated. R.Kristiawan noted that as Southeast Asian countries, aspersion issues, either individual or group, still become obstacle for press freedom in Indonesia. Application of the aspersion article firstly by the Government of Dutch-Hindia Colonialism to muffle and to hamper freedom of expression and opinion in public during the era of national movement. After Indonesian independence, the state remain cause to be effective articles of "defamation, degradation, and aspersion, both spoken and written) to Civic Code. Since Civic Code is the prime of civic laws in Indonesia, thus many Laws still using the principle of defamation. The latest Law caused to be effective is Law No.11/2008 on Electronic Information and Transaction (UU ITE). Advancement of technology seems not automatically balance with proper legal infrastructure (Kristiawan 2011).

Defamation in English phrase is excessively translated to bahasa as "degradation and aspersion". In this context, criminalization to freedom of expression indeed has wider to common people after the born of UU ITE. In May 2008, Tifa Foundation was supporting some Civil Society Organizations (CSOs) to make judicial review to UU ITE. Unfortunately, the effort was failed. Few months later there was "The Case of Prita Mulyasari". Prita's personal complaint through mailing list network about poor quality services of international hospital considered have aspersed image of the hospital. She has been prosecuted, jailed, and then freed. When the court fined her Rp 204 million, public was reacting. Support and solidarity to Prita cared through Facebook and Twitter in the movement "Coins for Prita". Smal change moneys gathered to more than Rp 600 millions. This case made Minister of Law and Human Rights do judicial review.

According to R.Kristiawan, there are several defamation accusations through newspaper and internet as following: 1). 13 May 2005: Revrisond Baswir, economy commentator from Gadjah Mada University, being reported to Regional Police Station of Yogyakarta on aspersion accusation of SCTV through his writing in internet mailing list. Afterward, Revrisond excused to SCTV and SCTV leaved its accusation. 2). 14 July 2008: Parliamentarian of National Mandate Party (PAN), Alvin Lie, reported case of assumed aspersion by Iwan Piliang to him through writing in internet mailing list. 3). 16 November 2008: Erick Adriansjah, a broker of PT Bahana Securities, seized by police on aspersion accusation through electronic mail mentioned there are 5 banks with difficulty of liquidity. 4). 18 April 2008: State court in North Jakarta punished Pan Ester to pay compensatory in the amount of Rp 1 billion to PT Duta Pertiwi, because evidently making a mistake of aspersion the company through writing in reader rubric of a newspaper. The court accepted his consideration request and cancelled the obligation to pay compensatory. 5). 14 May 2009: Head of Residents of Mangga Dua Court Apartment, Jakarta, Fifi Tanang served a sentence 6 months with trial period 1 year by State Court of South Jakarta in a case of aspersionof PT Duta Pertiwi through reader letter. 6). 3 June 2009: Prita Mulyasari freed from detainee and got status as city detainee after 20 days in Women Prison in Tangerang, in a case of aspersion of Omni International Hospital, Alam Sutera, Tangerang, through writing in internet mailing list. His penal case is ongoing. 7). 4 June 2009: Khoe Seng Seng and KwieMeng Luan alias Wenny served a sentence 1 years respectively by State Court of East Jakarta in a case of aspersion through writing in rubric of reader letter, in a newspaper 
(Kristiawan 2011). On the other hand, in 2010, until November, AJI noted there are 43 cases of violence to journalist and pers. A quite horrendous case stick up high in that year was accusation of National Police to Tempo Magazine. The accusation related to cover picture of Tempo magazine, edition of "Potbellied Account of Police Office" figuring a police officer bringing three pigs.

The problem is not always in matter of positive law and classic rhetoric of law enforcement, it also including influencing paradigm in the process of law making. Today, process of law making in Indonesia still based on colonial paradigm assuming expression of every citizen as source of danger to instability, thus it considered proper to be criminalized. Actually, what is fundamental problem of defamation? Paradigm of criminalization of "aspersion" actually is not only violating constitution, but also despising three indicators of democracy, namely freedom of expression, freedom of speech, and freedom of press. Therefore, Press Law could be said as an important foundation in history of press freedom in the country, as it "ignore" principle of Penal Code (KUHP) on aspersion and replaced it by mechanism of right to response. However, the matter also set in a context of court as using of Press Law or Penal Code (KUHP) utmost depend on appetite of judge committee. Incarceration of Risang Bima Wijaya in Yogyakarta and Bersihar Lubis in Medan with accusation of aspersion happened because judge referring to Penal Code (KUHP) in threatening the case of them. This is gap that often used to deceive journalist and press criminally, namely by using of KUHP as reference and not Press Law. Although Appellate Court have released Appellate Court's Legal Document in 30 December 2008, principally stated that all press disputes have to pass through official statement of Press Council, however, KUHP still obtained in press disputes. The ideology behind aspersion actually is perpetuation of power: aspersion frequently used as pretext to perpetuate power (Kristiawan 2011).

\section{About the second wave reform}

Indonesia's Independence on August 17, 1945 is the result of the struggle of the Founding Fathers consisting of intellectual, youth activists, students, fighters, community and religious leaders who are united with the people in the grass root. In its development later, the army of people was born from the civil society including nationalist and Islamic forces, which were together with all groups to fight for the independence, preserve and develop independence. There are still many things that have yet to be reached by them.

Ideas and ideals of the Founding Fathers are to realize a fair, prosperous and peaceful nation-state, free from oppression and colonization from the external and internal. Independence was articulated by Bung Karno as a "golden bridge" to achieve the ideal of glory. But, in the era of Reform, it appears that the "golden bridge" is broken or collaps in part, because the behavior of the rulers (the political and economic elites) who conspire and collude to dredge and control the wealth and power for their own interests.

The practice of democracy in Indonesia is currently being taken hostage by the political elite for self and group interests. Consequently, the goal of democracy for the welfare of the people, creating a security and intellectual life of the nation that had not been achieved. The political elites are now taking hostage democracy for their group interests. One of the symptoms is seen from the rampant corruption in all layers of bureaucracy, the weakness of law enforcement, and disruption. All of them tie up democracy, which should aim to fight for the interests of society.As a result of the democracy hostage, the people's basic rights are not met by the government and the state, including religious freedom, security, or economic prosperity. The practice of democracy is getting worse, as officials and politicians lose morality. The performance of political elite no longer refers to sources of values, common sense and humanity, but mastered by the lust to gain power and materials. Consequently, many officials are involved in corruption cases because use the power for the sake of their interests (Sahrasad et al. 2011).

In the opaque situation, students and the press see Indonesia today requires comprehensive social movements from the community level to improve the situation. Therefore, students as one of the 
main pillars of reform and the agent of change are expected by the press to initiate the flow of changes, while disseminating discourse of equality, social justice, and anti-corruption ranging from college level to the grassroots level. The students must remember that the condition of the state increasingly deviates from the ideals of our founding fathers because of the political elite who care only the interests of their own, law enforcement is weak/bad, and the political system is controlled by political party. So it requires the third volume of reforms by the student and activist movement as a social movement to improve the state institutions and law enforcement, screen officers, and improve the political system.

With the increasingly widespread corruption, worsen poverty and unemployment, fragile security, as well as the nation's declining morality which its continuance could damage the building of this country, even threatened with bankruptcy. In my opinion, the threat must be anticipated by students and activists, by encouraging the third volume reform movement. The first Reform caused the first President Suharto went down from power in 1998, while this gradual Reform by President BJ Habibie, Abdurrahman Wahid, and Megawati Sukarnoputri is continued to change the political system.

The second reform is aiming to fix unfinished things in government, for example, in the future, the public officials and legislators in the DPR (House of Representative) and DPRD (Local House of Representative) should be filtered by the Independent Commission through the academic potential tests, psychological tests, and commitment test to net leadership and staffs that have quality and integrity at both the national and local levels (Sahrasad et.al. 2011). By the press and students who complete, cooperate, trust one another, and by consistent and continued social movements to reform the state and nation, Indonesia would be able to improve the legal system and clean up governments officials who mostly contaminated by corruption. Political recruitment should be enhanced by selecting candidates in legislative, executive and judicial officials. In turn, in the writer's opinion, all this will be able to create a government that serves the public welfare, enforces the law, nation, and defends national sovereignty. Indeed, history is waiting for the initiative of the press, students and activists for Indonesia's future reform.

The question is: Is it true that the press of Indonesia in the post-Suharto Reform era has been independent? Is it true that the press has been struggling for a broader public interest? In the midst of mastering a number of media by conglomerates and politicians, the presence of the press is one of the most important institutions in building the nation's three pillars, namely prosperity, democracy, and justice. Press should maintain their neutrality so it does not dissolve into a part of a conglomerate or capital strength. This is why 'no money, no voice' phrases should be prevented from becoming a common practice in the press and journalism in the country that embraced democracy.

Above all, the mass media is very strategic in nature, because its presence can prevent the domination and hegemony coming from one of the actors from the three arenas: the executive, legislative and judicative. Presiden Yudhoyono and Coordinating Minister for Political and Security Affairs Djoko Suyanto ask the press to not struggle for the interests of capital owners and any political power (Sutanto 2010). In the past, someone entered the media business always with ideals and intentions to struggle, for either free flow of information, democracy or the nation learning. The independence and objectivity become his/her blood stream. Later, the entrepreneur interests in the media business are not only in the aspect of idealism, but also in the business benefits and the access to power and politics. It is not surprising that the press industry in Indonesia is filled by political forces. In the past, we know Pelita newspaper (PPP) also Suara Karya (Golkar-up to now). Even now there are numbers of political power entering the world of media, the Democratic Party through the National Journal, for example.

In facing the capital strength, Ashadi Siregar, a media expert from Gadjah Mada University and the student press figure of his day, warned that the position of journalists as press 'prima donna' can be swallowed by the editorial management and capital as they can not set the editorial component 
proportionally as a sub-system of the whole system. The development of the press that are closely associated with social dynamics requires journalism professionals to continue formulating new ethical perspectives, forging personals to put themselves into their profession to face the audiences, the media investors, economic power and state power. Looking at the complexity of the problem of poor and inefficient management, while corruption scandal is so rampant and capital movements enter so massively into the mass media in the mid of the chronic poverty faced by the post-Suharto Reform regimes, press in Indonesia would continue to serve as democratic control and public opinion in the boundaries of existing capacity, as its social responsibility for the interests of the nation and the state. It is never-ending duties of the media in Indonesia to face these complicated challenges in the future.

\section{Conclusion}

As the fourth pillar of democracy, press held the responsibility to provide public information in the most objective way. This condition should also be accompanied by press freedom provided by the government. The more a government guarantees the freedom of press, the more democratic the government is. This article found that this press system in Indonesia have decayed by several problems lying in oligarchy system. After the new order era with its authoritarian rule, Indonesia moves toward a transition phase called constituional democracy. But in current leadership, the practice of democracy was not ideal as it is expected. Corruption was rampant, high economic gap lies between the rich and the poor, and there was crisis of public trust to the authority in society. Under the era of SusiloBambangYudhoyono-Boediono, press and media was influenced by the practice of criminal democracy, indicated by money politics and the increasing use of violence. Press and mass media can't do anything but to ignore the fraud and intimidation by the elite. Politician commited corruption to revive their capital used to fund their campaign in the election, resulting he widespread of criminal democracy significantly.

Responding this situation, students in Indonesia shows their concern about the dynamics in the government. At this point, press has the roles to publish those critical voices as balaner and reminder to the government. SBY regime was viewed as an era with weak national leadership and provide limited solution to the problems in the society. In order to change this situation, students believed in the continuance of the spirit of Reformation 1998 that yet had not been completed. This movement was expected to offer alternative leadership figures. Students also see that oligarchy and the role of the central figures of the party causing damage for political culture in Indonesia. Political party's movements are highly influenced by power and capital, and ignoring Pancasila as ideology of this nation.

I conclude that press should continue to be the fourth pillar of democracy, to be consistent in carrying its vision and mission based on the principle of good journalism. The accumulation of those critical issues and the absence of strong governance would lead to state's failure. Democracy needs to get back to its track, as it is important in guiding this nation, particularly in press freedom issues. Social change is needed by whole aspect of this nation, particularly from student and press, so that the national circumstances could be improved for betterment.

\section{References}

Batubara L (2007) Masalah-masalah dalam perusahaan pers Jakarta. Jakarta: Dewan Pers.

Bhakti I N (2011) Oligarki dan demokrasi, Seputar Indonesia, 7 June.

Chomsky N (1972) New Horizons in the study of language and mind. Cambridge: Cambridge University Press.

Harimurti B (2011) [Personal communication] November.

Kompas (2011) Mahasiswa risaukan situasi bangsa. Kompas, 7 July 2011.

Kompas (2011) Pemerintah lupakan kepentingan rakyat. Kompas, 7 August 2011.

Kristiawan R (2011) Jerat negara dan pasar dalam ruang publik, Prisma vol. 30 no. 1 p. 45-58

Kundera M (1979) The book of laughter and forgetting, New York: Viking. 
Kunio Y (1987) The rise of ersatz capitalism in Southeast Asia. Singapore: Oxford University Press.

McNair B (1988) The sociology of journalism. London: Hodder and Stoughton in Paperback.

Muzakki (2008) The captured state; fenomena dominasi modal atas kekuasaan pemerintah dalam kasus Tempo, Dissertation, Brawijaya University, Malang.

RamliR (2011) "Perubahan adalah jawaban, perubahan sekarang juga," Pidato Kebudayaan, Taman Ismail Marzuki, Jakarta, 4 May.

Robison R \& Hadiz VR (2004) Reorganising power in Indonesia: the politics of oligarchy in an age of markets, London \& New York: Routledge.

Sahrasad H, Triyana B, Rachman MF \& Rizal JJ (2011) Demokrasi disandera elite jangan terjebak dalam pesimisme. Kompas, April 16, p.3.

Siebert FS, Peterson T \& Schramm W (1963) Four theories of the press. Urbana: University of Ilinois Pres.

Siregar H (2010) [Personal communication] 1 May.

Sudarsono J (2011) Demokrasi dan oligarki, Kompas, 11 May.

Supriatma AMT (2009) Menguatnya kartel politik para "boss". Prisma, Oktober 2009, p. 3-14.

Surjomihardjo A (ed.) (2002) Beberapa segi perkembangan sejarah pers di Indonesia. Jakarta: Penerbit Buku Kompas.

Syaukanie L (2011) Tantangan kebebasan berpikir dan berekspresi di Indonesia. Prisma, vol.30.No.1, 2011, p.38-4.

Winters J (2011) Oligarchy, Cambridge: Cambridge University Press.

Wisesa SA, Kalla J, Baswedan A, ZonF, Subiharto BA (2011) "Political branding dan launching buku political branding dan public relation", Postgraduate School Campus, Paramadina University, Jakarta, 21 July. 